tially trivial (as in The Masters), just as Snow was himself an inveterate pothunter and seeker after life's baubles.

The most interesting of the novels remains The Search, for it describes, often with compelling immediacy, the people and episodes that directed the course of Snow's academic life. The hero, Arthur Miles - again Snow - is thwarted in his purpose to become director of a new biophysics institute by the untimely discovery of a fearful gaffe in the work that has made his name. Crushed by disappointment and humiliation, which his professional rivals do nothing to assuage, Miles rejects the advice of a friend to apply himself patiently to his métier and rebuild his reputation, and resolves instead to forsake science and seek fame as a Man of Affairs. What a piffling reason, J. B. S. Haldane commented, for giving up the privilege of a life in research — the mere frustration of a personal ambition! But Snow was first and last an arriviste, whose interest was not in the journey, only in the goal. His own research, of which de la Mothe gives an absorbing account, was an almost unbroken succession of boners, the consequence most often of intellectual delinquency or wanton carelessness. The climax came with the publication by Snow and Philip Bowden (Francis Getliffe in the Strangers and Brothers series) on the spectroscopic identification and supposed photochemical generation of vitamin A. Their claims were brutally anatomized by Ian Heilbron and R. A. Morton. In particular, and not for the first time, Snow had made a fool of himself by his ignorance of the literature; he was probably already too busy with his other ambitions to bother with reading journals.

The metamorphosis of Percy Snow (as he was known to his fellow-students, who found him such a pest, in the chemistry laboratories at Leicester) into Sir Charles and later Baron Snow, his rise to the status of sage to that unsettled decade, the sixties, and the curious growth of his literary reputation make an interesting moral tale that repays study. Snow went far on his catch-phrase, The Two Cultures, but the idea was not new: Waddington, Koestler, Bernal, Polanyi and many others had articulated the same concerns, as in an earlier generation had H. G. Wells, a better writer by far than Snow and an altogether deeper intellect. That grandee of the other culture, Max Beerbohm, spoke of Wells's prose as "cold rice-pudding, spilled on the pavements of Gower Street". Why, then alas for Snow.

Walter Gratzer is in the MRC Muscle and Cell Motility Unit, King's College London, 26-29 Drury Lane, London WC2B 5RL, UK.

\section{Imbalances of power}

Lawrence Freedman

Closing Pandora's Box: Arms Races, Arms Control and the History of the Cold War. By Patrick Glynn. Basic Books: 1992. Pp. 445. \$30.

DURING the 1980 s, US arms-control policy came under the increasing influence of a collection of neo-conservatives who were highly dubious about the whole exercise. Many of them, including Richard Perle in the Pentagon, had been homicide squad. They were therefore somewhat surprised that the decade concluded with a spate of dramatic breakthroughs in arms control. The main reason for this was the collapse of Soviet inner strength and self-confidence, which led to an almost craven acceptance of whatever the Americans happened to be proposing at the time. This raised questions about the relationship between attempts to regulate armaments and the overall balance of power.

The old liberal hope was that by containing the arms race, not only would the danger of war by accident or miscalculation be reduced but so too would a major source of aggravation in political relations. By the 1980 s one did not have

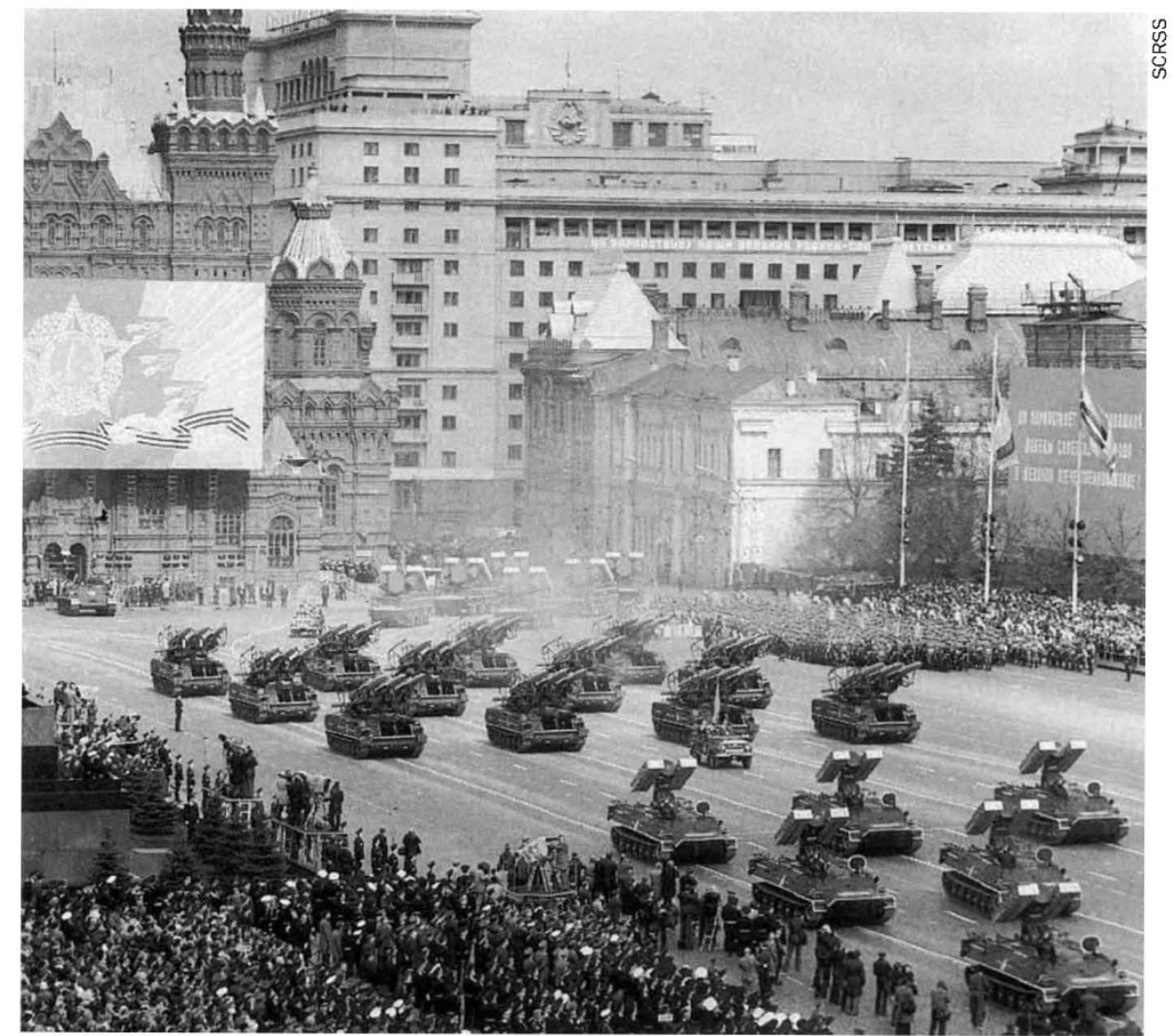

End of the road - the collapse of Soviet power can be traced to the cumulative Inefficiencies of state socialism, as much as to any external pressures from the West.

previously associated with Senator Henry Jackson. They argued that their predecessors had paid far too much attention to 'negotiability' to the neglect of substance, so that deals had been applauded even when they were to the detriment of the West's security. By acting as if the details of the military balance did not matter, they had allowed the balance to tilt dangerously to the Soviet's advantage. Reflecting President Reagan's own views, they did not put a high premium on 'negotiability' when they did get around to negotiating.

Liberals thought that the prominent position of this group in arms-control posts in the Reagan administration was akin to putting Crippen in charge of the to be a conservative to appreciate the problems with this perspective. In practice, when relations were tense, armscontrol efforts tended to make matters worse, through, for example, arguments over compliance; when relations were improving, arms control at best reinforced the benign trend. Against the underlying liberal assumption that there was little other than mutual fear and suspicion driving the great powers to war was the unfortunate reality that the East-West confrontation was not simply an unfortunate misunderstanding but reflected real differences in ideology and interests.

The neo-conservatives took up this 'realist' position, but then turned it into 
a dogma of their own. Their view was that when status quo powers such as the United Kingdom and the United States are faced with a radical power determined to upset the established order, they must pay attention to the military balance. If the liberal democracies allow their guard to fall because of fond hopes that restraint will be reciprocated and a spirit of goodwill created, they will simply find themselves at a chronic disadvantage should the crunch arise.

Patrick Glynn worked in the Arms Control and Disarmament Agency from 1986 to 1989 and is now at the American Enterprise Institute, a conservative think-tank. In this book he provides the most developed version of the realist thesis. It is much more than a polemic or a memoir (of which there have been a number recently). It is a well-researched analysis of the history of attempts to use controls on weapons to ease political tensions.

Glynn starts with Sarajevo - the 1914 rather than the 1992 version. The start of the First World War is often cited as the classic example of how catastrophic wars can be the product of arms races (in this case the Anglo-German naval competition) and mobilization plans that allow little time for effective diplomatic management of crises. Drawing on the weight of contemporary historical research, he demonstrates that the basic problem was the German determination to overturn the status quo and that deterrence failed because expressions of liberal sentiment gave German hawks hope that Britain in particular would stay on the sidelines. He then follows this through by looking at the more familiar story of the paths full of good intentions that led to the Second World War, and then the shift of gear as the Western democracies came to terms with what they judged to be the long-term intentions of their erstwhile ally, the Soviet Union.

In the process of all this, Glynn marshals his evidence effectively, makes several novel and interesting points, and writes clearly. The difficulties with his approach lie more in the second part of the book where he applies this analysis to the Cold War. He assumes that power politics have continued to be in play throughout this period. Thus he takes the variations in the military balance to be of considerable importance, to the point where the collapse of the Soviet Union is traced to Gorbachev's stark realization that he could not cope with the challenge posed by Reagan's military build-up, including the Star Wars programme.

Hcre the narrative becomes too synoptic and the context too blurred. By stressing the continuities with the past, Giynn ends up missing the discon- tinuities. The power politics of the first half of this century was followed by a period in which the political order congealed, at least in Europe. Without any real threats of war, the nuances of the military balance became far less important than was claimed by both the hawks and the doves.

The Soviet Union ceased to be a radical power but instead developed its own stake in the status quo and feared US radicalism. But the key instrument of this radicalism was not the arms race, but the strength of the economic system it represented and the political values it espoused.

Ironically, given the conservatives' distaste for détente, it was the stress on human rights inserted into the 1975 "Final Act" of the Conference on Security and Cooperation in Europe that eventually undermined the Soviet system, as much as any other external pressure imposed by the West. Glynn does not mention this conference, perhaps because he finds it difficult to accept that anything good could have come out of the Kissinger era, though he acknowledges the importance of the West's demands for human rights. When Gorbachev began to face the need for reform, he acted to gain Western support by offering concessions on the key areas of Western concern - arms control, regional conflicts (such as Afghanistan) and human rights. In each case it suited his own purposes. But what finished him was an area in which no demands had ever been made - the cumulative inefficiencies of state socialism, which had reached the point where they were beyond reform.

Lawrence Freedman is in the Department of War Studies, King's College London, Strand, London WC2R 2LS, UK.

\section{Promethean prescription}

\section{Timothy O'Riordan}

Green Delusions: An Environmentalist Critique of Radical Environmentalism. By Martin W. Lewis. Duke University Press: 1992. Pp. 288. \$24.95, £21.

FOR Martin Lewis, radical environmentalism rests on four essential postulates, namely that primitive or primal people exemplify how to live in harmony with the natural world and with each other; that thorough-going decentralization based on autarchic self-reliance is necessary for ecological and social health; that technological advance, if not scientific progress itself, is inherently harmful and dehumanizing; and that the capitalist market system is inescapably destructive and wasteful.

In its place he advances the cause of promethean environmentalism, arguing that enlightened sophisticated people can learn to come to terms with nature and their own existence; that cooperation based on trust and scientific understanding should underpin future government; that technological development can be made environmentally benign if the right signals are put in place; and that a socially guided, more strategically caring capitalism is vital for the transition to sustainability. A healthy society, he concludes, is one characterized by simultaneous advances in general prosperity, social equity and environmental stability.

The text itself is a well referenced analysis of the radical view and a less convincingly argued case for prometheanism. But Lewis falls into the trap of setting up stereotypes to represent what are really fragmentary minority positions. Few intelligent analysts of environmental values espouse what Lewis characterizes as radical environmentalism. True, there are some biggish names such as Murray Bookchin, Rudi Bahro and David Pepper who write about deep greenism and the sociology of the commune. But the heartland of modern environmental theory is closer to Lewis's position than he is prepared to admit. Indeed, his analysis smacks of a flexible and adaptable environmentalism that most social democrats, or old-style liberals, already proclaim as their territory.

In many ways, therefore, Lewis is tilting at windmills when the real target lies uncomfortably in his own stance, itself dangerously off balance. No one seriously believes that any of the four postulates is either 'true' or a blueprint for the future. Even the most woolly of the Green Party activists see a role for benign technology, for some sort of social contract with commerce, for carrying degrees of national and international intervention in the otherwise corrupted capitalism of the modern environmental age, and for ensuring that indigenous peoples have dignity as well as a degree of political independence.

Nevertheless, Lewis's argument is a goldmine of thoughtful assessments of a wide range of social reasoning in the modern environmentalist debate, and he incorporates text that will probably be new to even the most well read of readers. Of special value are his insights into the relationship between capitalism, the state and the longer-term public purpose. Here is one arena where mod- 